\title{
Selected Reference Books of 1960-1961
}

\author{
By CONSTANCE M. WINGHELL
}

\section{INTRODUCTION}

$\mathrm{L}$ IKE THE PRECEDING ARTICLES in this semiannual series, ${ }^{1}$ this survey is based on notes written by members of the staff of the Columbia University libraries. Notes written by assistants are signed with initials. ${ }^{2}$

As the purpose of the list is to present a selection of recent scholarly and foreign works of interest to reference workers in university libraries, it does not pretend to be either well-balanced or comprehensive. Code numbers (such as All, 1A26, 2S22) have been used to refer to titles in the Guide $^{3}$ and its Supplements.

\section{BIBLIOGRAPHY}

SANB; Suid-Afrikaanse nasionale bibliografie. South African National Bibliography, 1959. Pretoria, State Library, 1960- . [v.1]Quarterly with annual cumulations. (Published monthly during 1959).

This new national bibliography attempts to list all printed material published in South Africa, including books, pamphlets, maps, etc. Arranged by Dewey decimal classification, detailed information is given on author, title, publisher, date, paging, illustrations, centimeter size, and price. There is a separate section listing official publications, and in the 1960 volume a listing of periodicals received for the first time, periodicals with change of title or address, and periodicals which have ceased publication. The general author and title index does not include the periodical listings.

Pennsylvania. University. Library. Catalog of the Programmschriften Collection. Boston, G. K. Hall, 1961. 117, 260p. $36 \mathrm{~cm}$. $\$ 22$. Index (117p.) compiled by Albert R. Schmitt and drawn from article in v.25, no. 1 of the $L i$ brary Chronicle.

Frequently of considerable value but rarely

${ }^{1} C R L$, January and July issues starting January, 1952.

Reference: Eleanor Buist, Rita Keckeissen, Evelyn Lauer, Elizabeth J. Rumics, Eugene Sheehy, John Neal Waddell.

${ }_{3}$ Constance M. Winchell, Guide to Reference Books (7th ed.; Chicago: ALA, 1951); Supplement (Chicago: ALA, 1954); Second Supplement (Chicago: ALA, 1956); Third Supplement (Chicago: ALA, 1960).
Miss Winchell is Reference Librarian, Columbia University Library.

indexed in general or national bibliographies, Programmschriften-papers on scholarly topics by faculty members of German Gymnasientoday are often hard-to-identify and elusive publications. In 1954 the University of Pennsylvania Library acquired a collection of over sixteen thousand Programme written between 1850 and 1918 , one third of which deals with topics in the humanities. The present bibliography reproduces the author cards for this group, including a few on the history of science, and provides a subject index. The balance of the collection, dealing with science and therefore more or less obsolete, is not indexed. Two minor drawbacks to this somewhat specialized book: pagination of each Programm is not given; and the introduction implies but does not specifically state that items are available on interlibrary loan.-E.J.R.

\section{Periodicals}

Boehm, Eric H. and Adolphus, Lalit. Historical Periodicals; an Annotated World List of Historical and Related Serial Publications. Santa Barbara, Calif., Clio Press, 1961. 618p. \$22.50.

"An annotated directory of serial publications which contains articles on historical topics" (Introd.), compiled by the editors of Historical $A b$ stracts and listing some five thousand current titles. It includes transactions, acta, and irregular publications not ordinarily classed as periodicals and interprets "history" in the widest sense. Arrangement is geographic by large region and by country, and alphabetical by title within a country. Journals concerned directly with history and its auxiliary disciplines are given long entries with information including title, subtitle, frequency, beginning date, most recent volume examined, publisher, editor, description of contents, subscription price, and, often, notes on special features. Titles in fields related to history rate less space and information. Cross references and an index of titles make the volume easy to use.-R.K.

Zimmerman, Irene. $A$ Guide to Current Latin American Periodicals: Humanities and Social 
Sciences. Gainesville, Fla., Kallman Pub. Co., 1961. 357p. $\$ 20$.

"Primarily an annotated, evaluative bibliography .. . comprehensive within defined boundaries and selective beyond those limits" (Introd.), this Guide lists 668 active periodicals and 117 on its "casualty list" from 26 countries. The term "Latin American periodicals" is interpreted to mean those published in South and Central America, Mexico, and the West Indies, as well as those published in the United States by Latin Americans and inter-American agencies, and others dealing extensively with Latin American languages or literatures, or published in the United States for Latin American circulation.

The principal arrangement is alphabetical by country, followed by a classified section and a chronological listing. Each country and each section has an explanatory introduction.

Annotations are given in the country section and are full in descriptive and evaluative information on editors, history, coverage, policies, volumes published, last issues received, and many other useful details. In the second section, the periodicals are grouped by subject field, again with introductions, and in the chronological section, the history of periodical publishing is given by period. The "casualty list" records those periodicals from which it has not been possible to elicit recent information.

\section{Periodical Indexes}

Leavitt, Sturgis Elleno. Revistas hispanoamericanos; indice bibliografico, 1843-1935, recopilado ... con la colaboración de Madaline W. Nichols y Jefferson Rea Spell. Santiago de Chile, Fondo histórico y bibliografico José Toribio Medina, 1960. 589p. (Available from the compiler, Box 1169, Chapel Hill, N. C.) $\$ 19.50$.

More than thirty thousand articles from fiftysix Spanish-American journals of the period 1843-1935 are listed in this new index. A classed arrangement is used, and entries are listed alphabetically within the sections. References are to volume and page; dates are omitted. There is a separate section for translations, subdivided by language, then by literary form. An index of names adds to the value of the work. It is highly gratifying to have a periodical index from this area covering so long a period.-E.S.

L'U.R.S.S. et les pays de l'est; revue des revues. No. 1- . Mai 1960- . Paris, S.E.D.E.S., 1960- . Quarterly.

At head of title: Faculte de Droit et des Sciences Politiques at Économiques de Strasbourg, Institut de Droit et d'Économie Compares,
Centre de Recherches sur l'U.R.S.S. et les Pays de l'Est.

In 1959 a center for research on the U.S.S.R. and eastern Europe was established in Strasbourg. The first number of its abstract journal presents selected abstracts in French from forty Russian, Polish, and Yugoslav periodicals. Material is arranged under the four main categories of law, economy, social life, and culture. Part I, Bulletin analytique, contains page-length abstracts of the most important articles, giving objective summaries of content, which at times may be accompanied by notes in which reviewers may express opinions. Part II, Repertoire systematique, lists all articles in the journals under review.-E.B.

\section{NEWSPAPERS}

U. S. Library of Congress. Union Catalog Division. Newspapers on Microfilm. 4th ed. Comp. under the direction of George A. Schwegmann. Washington, 1961. 323p. \$4.

For 3d ed. see Supplement 3E48.

This edition has been revised and enlarged to contain approximately thirteen thousand entries, including about 2,580 foreign newspapers. It lists microfilms of Russian newspapers up to 1957 as in the $3 d$ edition.

\section{Government Documents}

Bibliographical Society of the Philippines. Checklist of Philippine Government Documents, 1917-1949. Compiled by Consolacion B. Rebadavia. . . Edited by Natividad P. Verzosa and Pacifico M. Austria. Quezon City, University of the Philippines Library, 1960. 817p. mimeographed.

This retrospective bibliography of more than six thousand items issued by all branches of government "attempts to fill the gap covering the period immediately following the compilation of Elmer's Checklist of Publications of the Government of the Philippine Islands, September 1, 1900, to December 31, 1917 and closing with the 1950 Checklist [Supplement 2F13] compiled by the Bibliographical Society of the Philippines. . . " (Pref.) It includes 1917 imprints omitted from the earlier list. A special effort was made to include documents issued during the Japanese occupation.

Entries are arranged alphabetically by name of the issuing office; for serials, individual issues are listed with their dates. A supplement of material found too late for inclusion is in preparation. Each entry gives author, full title, place and date, paging, and (often) size. A full index of subjects and personal names, both as authors and subjects, refers to the entry number.-R.K. 


\section{RELIGION}

Burr, Nelson R. A Critical Bibliography of Religion in America. Princeton, N. J., Princeton Univ. Press, 1961. 2v. (Princeton Studies in American Civilization, no. 5). \$17.50.

Being the final volume (bound in two) of a series of four volumes, Religion in American Life, by James Ward Smith and A. Leland Jamison, this is a comprehensive bibliography in classified arrangement with running commentary. Following a section devoted to bibliographical guides, general surveys and histories, the rest of the first volume (pp. 87-541) discusses the growth of religion in this country, and the individual denominations and sects, missions, non-Christian religions, etc. The three sections in the second volume treat religion in American life and culture, including the arts and literature and intellectual history. There are full tables of contents and an author index, but no subject index.

Hills, Margaret Thorndike. The English Bible in America; a Bibliography of Editions of the Bible and the New Testament Published in America, 1777-1957. New York, The American Bible Society and The New York Public Library, 1961. 477p. \$13.50.

The advent of this well-printed bibliography offers a chronological annotated listing of some twenty-five hundred separate editions of American-printed Bibles. Additional editions are noted in descriptive annotations, which generally give size, full imprint, and a library location, where known, as well as comments on appearance, printing, and the like. The listing is based on the American Bible Society's collection, checked against the holdings of the New York Public Library and the Library of Congress, as well as various bibliographies. The foreword and introduction are followed by a brief history of Bible printing in America; Part I, Editions 17771825; Part II, Editions 1826-1957; and Indexes of: place of publication; publishers and printers; translations, translators, and revisers; editors and commentators; edition titles; and a general index. "A similar publication covering editions in other languages may eventually be prepared." (Introd.)-E.J.R.

\section{Social Sciences}

Hamburg. Welt-Wirtschafts-Archiv. Verzeichnis der Fest- und Denkschriften von Unternehmungen und Organisation en der Wirtschaft. Hamburg, 1961. 566p. (Its Veröfentlichung) DM.15.

A listing of more than four thousand Festschriften and histories of firms and companies. International in scope, but mainly German, it lists works published in this century that are found in the Archiv. In classified arrangement with indexes by: author and personal name; firm; and geographical location.

It is particularly strong in the histories of individual companies, many of which are not listed in general and national bibliographies.

Hsïeh, Chün-tu. The Chinese Communist Movement, 1921-1937; an Annotated Bibliography of Selected Materials in the Chinese Collection. . [Palo Alto] Hoover Institution on War, Revolution and Peace, Stanford University, 1960. 131p. (Hoover Institution Bibliographical Series, 8) $\$ 2.50$.

Another in the series of bibliographical publications attempting "to describe and evaluate the more important holdings in particular area collections" of the Hoover Library, this work lists 359 items selected from books, periodicals, newspapers, and manuscripts in the Chinese collection. Arrangement is by historical period, then by topical subdivision. Main entries and titles are given in both romanized form and in Chinese characters; annotations are descriptive and critical. There is an index of authors, titles, and subjects.-E.S.

Index to Labor Union Periodicals: a Cumulative Subject Index to Materials from a Selected List of Newspapers and Journals Published by Major Labor Unions. Ann Arbor, University of Michigan, Bureau of Industrial Relations, 1960- .v.1- . Monthly.

A subject index to forty-one labor union periodicals, which is to have cumulative semiannual and annual volumes. It is hoped that indexing may be expanded to work backwards, year by year, beginning with 1959 .

South Africa. Office of Census and Statistics. Uniestatistieke orr vyftig jaar; jubileumuitgawe, 1910-1960 ... Union Statistics for Fifty Years; Jubilee issue. [Pretoria, 1960] 1v. (various pagings) $£^{1.1 \mathrm{~s}}$.

With the increasing interest in African studies, a statistical survey of this kind becomes particularly welcome. An anniversary volume, it "presents a statistical resume of the Union's growth and development over the past halfcentury." There are sections of tables for population, vital statistics, education, labor, agriculture, industry, etc., with a detailed table of contents and a section of notes for each. Sources are frequently indicated, but these suggest that the figures were more often supplied by government departments than taken from published reports. The work is bilingual throughoutEnglish and Afrikaans. Unfortunately, there is no general index.-E.S. 
U. S. Bureau of the Census. Congressional District Atlas of the United States. April 1, 1960. Washington, U. S. Government Printing Office, 1960. 99 p. 55 \&.

Gives maps of the Congressional districts by state and city and shows the boundaries at the time of the 1960 Census of Population. Reapportionment will necessitate a revision of these maps.

\section{Education}

Eells, Walter Crosby and Haswell, Harold A. Academic Degrees. Washington, U. S. Government Printing Office, 1960. 324p. (U. S. Office of Education Bulletin 1960, no. 28, OE-54008) $\$ 1$.

A useful compilation of information on higher degrees conferred by American colleges and universities, this volume includes twenty-four hundred degrees (sixteen hundred currently in use) arranged in three principal lists: classified by field, alphabetical by name of degree, and alphabetical by abbreviation. Preliminary chapters incorporating much historical and statistical information are devoted to types of degrees and institutions, women's degrees, honorary degrees, and spurious degrees.-R.K.

\section{DictionaRIES}

Burrow, Thomas and Emeneau, Murray Barnson. A Dravidian Etymological Dictionary. Oxford, Clarendon Press, 1961. 609p. $\$ 20.20$.

The Dravidian languages comprise a group of tongues spoken throughout southeastern India and northern Ceylon, including four literary languages, and many nonliterary ones. This dictionary attempts to give the etymologies of words in all known Dravidian languages, with English equivalents. Selective bibliography of sources, p. xxiii-xxvii.

Partridge, Eric. Dictionary of Slang and Unconventional English: Colloquialisms and Catch-phrases, Solecisms and Catachreses, Nicknames, Vulgarisms, and Such Americanisms as Have Been Naturalized. [5th ed.] London, Routledge and Kegan Paul, 1961. 2v. 105s (v. 2 only, 60s).

V.l, the Dictionary, is a reprint of the original edition of 1937 ; v. 2 , the Supplement, incorporates into one alphabet the Addenda of the second, third, and fourth editions, (with some revisions) and new material running to some one hundred thousand words. These additions consist mainly of new words and phrases, with the emphasis on slang, particularly of World War II.

\section{AbBreviations}

U. S. Library of Congress. Slavic and Central European Division. Bulgarian Abbreviations: a Selective List, prep. by Konstantin Z. Furness. Washington, U. S. Government Printing Office, 1961. 326p. $\$ 1.50$.

-Hungarian Abbreviations: a Selective List, comp. by Elemer Bako. Washington, U. S. Government Printing Office, 1961. 146p. $45 \phi$.

Similar in plan and arrangement to the library's lists of Polish and Russian abbreviations (Supplement 3M92 and 3M101), the present volumes each list twenty-five hundred to three thousand abbreviations. By design, emphasis is on the symbols for government agencies, military and other organizational titles. Some general terms are also included. In the Bulgarian list, the abbreviations are followed by transliterated initials, then by the full name in the original, and an English translation. The Hungarian list follows the same plan, except, of course, for transliteration.-J.N.W.

\section{SCIENCE AND TECHNOLOGY}

Marckworth, M. Lois. Dissertations in Physics: an Indexed Bibliography of all Doctoral Theses Accepted by American Universities, 1861-1959. Stanford, Calif., Stanford Univ. Press, 1961. 803p. $\$ 17.50$.

The first half of this bibliography lists by author over eight thousand dissertations, giving for each, author's full name, dissertation title, year and name of degree, institution, availability of copy, and reprint data, if any. The second half, called "Permutation Subject Index," is in reality a title listing, alphabetized by each significant word appearing in the title. The result, of course, is that each title is listed several times and that listings under such words as electric, gas, molecule, nuclear, and their derivatives seem unwieldy. For each title, reference is made by serial number to the full listing under author.-J.N.W.

New York Academy of Medicine. Library. Catalog of Biographies. Boston, G. K. Hall, 1960. 165 p. $\$ 14$.

A photographic reproduction of the shelflist containing "single biographies of physicians and scientists, with a few autobiographies, family histories, and occasional biographies written by physicians." (Introd.)

United Nations Educational, Scientific, and Cultural Organization. Bibliography of Interlingual Scientific and Technical Dictionaries. Bibliographie de dictionnaires scientifiques et techniques multilingues. Bibliografía de 
diccionarios cientificos técnicos plurilingües, [4 ed., rev. and enl.] [Paris] Unesco, 1961. 236p. (Its documentation and terminology of science) $\$ 3.50 ; 17 / 6 ; 12.50$ n.f.

For 3d ed. 1953 see Supplement 2 P8.

Arranged by universal decimal classification, this edition adds nearly nine hundred new dictionaries, and 133 new editions of works previously mentioned. There are an index by languages, an index by authors, and subject indexes in English, French, and Spanish. Introductory and explanatory material is also in these three languages.

U. S. Library of Congress. Science and Technology Division. List of Russian Serials Being Translated into English and Other Western Languages. 3d rev. ed. Washington, 1961. xiv, 28p.

This volume lists 139 scientific and technical journals by translated title, followed by transliterated Russian title, with an index by transliterated Russian title. There is also an index by subjects.

The main listing gives LC call number, frequency, date when translation began, and publisher.

\section{Fine Arts}

Lebel, Gustave, Bibliographie des revues et periodiques d'art parus en France de 1746 a 1914. Paris, 1951 [i.e. 1960] 64p. (Gazette des Beaux-Arts, 6th Series, v.38, janvier-mars 1951).

Published as a special issue of the Gazette des Beaux-Arts (dated 1951, but because of unforeseen circumstances not printed until October 1960), this bibliography attempts to give a complete listing of French periodicals concerned with the fine arts in France from 1746 to 1914. In addition to firmly established art serials, it also lists many of an ephemeral nature which were published in connection with exhibitions or sponsored by individual galleries and groups of art patrons. The main listing is alphabetical by title and includes dates of publication, publisher, location of the periodical in Paris libraries, and a brief critical annotation; the last seventeen pages are given over to a chronological list of titles.-E.L.

\section{Music}

Grove, Sir George. Grove's Dictionary of Music and Musicians. Supplementary volume to the 5 th ed., ed. by Eric Blom; assoc. ed., Denis Stevens. London, Macmillan; N. Y., St. Martins Pr., 1961. 493p. 80s., \$15.
The preface of this volume modestly states that "to bring the fifth [1954] edition [Supplement 2Q56] completely up to date has not been the principal aim in the planning ... ," but the actual result is substantially that. Material included is of three categories: first, a vast number of corrigenda items with exact reference to page and line in the fifth edition. Many of these seem of minor importance, while others are obviously significant. Secondly, there are numerous additions to or rewritings of the original articles, treating recent developments in a subject or events in a career. There are also several replacement articles, e.g., "Folk Music (Italian)" and "Xylophone." Finally, there are entirely new topics, discussing new terms, organizations, and a number of contemporary artists, some of the last curiously omitted from the 1954 edition.-J.N.W.

\section{LITERATURE}

Bibliografie van de vlaamse tijdschriften. Reeks 1: Vlaamse literaire tijdschriften van 1930 tot en met 1958. Compilers: Robert Roemans and Hilda van Aasche. Aflevering 1- . Hasselt, Heideland, 1960-

Contents: Aflevering 1. Dietsche warande en Belfort; 2. De vlaamse gids; 3 . Nieuw vlaams tijdschrift.

Following the plan and arrangement of Roemans' Bibliographie van de moderne Vlaamsche literatuur 1893-1930 (Guide R501), this series continues the indexing of Flemish literary periodicals. Each of the three issues thus far received indexes a single periodical and has separate sections for poetry, prose, drama, and literary criticism. Authors are listed alphabetically within the sections; writings of a single author are listed chronologically. The issues are separately indexed, each having two indexes of personal names: one of contributors, the other of author-subjects. The latter has a geographical subdivision and an additional subsection for names in the fields of music and fine arts. The refinements of the arrangement, while no doubt of value to the specialist, make the work unduly complicated for the general user.-E.S.

Castillo, Homero and Silva Castro, Raul. Historia bibliografica de la novela chilena. Charlottesville, Va., Bibliographical Society of the University of Virginia, 1961. 214p.

A fairly impressive amount of bibliographical information on Chilean fiction is to be found in this small volume. In addition to full citations for editions of Chilean novels and short stories, it includes listings for translations, references to first printings in periodicals, and many contents notes. Critical studies are not included. 
Arrangement is alphabetical by author, then chronological. There is an index of names (of translators, editors, etc.) not found in the main listing. -E.S.

\section{Critical Bibliography of French Literature;} David C. Cabeen [and] Jules Brody, general eds. v.3, The Seventeenth Century, ed. by Nathan Edelman. Syracuse, N. Y., Syracuse Univ. Press, 1961. 638p. $\$ 7.50$.

The latest volume in this excellent series (Guide R570, Supplement 1R58, 3R90) is not only a valuable unit in itself, but is significant in completing coverage in the field from the Middle Ages through the eighteenth century. (Work on the nineteenth century volume is well under way.) Scope and general organization of material remain as in the earlier volumes, the aim being to select and to evaluate, but not to be all-inclusive. Even so, nearly five thousand items are described.

Nine chapters are devoted to literary backgrounds, movements, and forms, with individual authors treated in appropriate sections; five separate chapters treat Corneille, Moliere, Racine, Pascal, and Descartes. Sections have been compiled by more than fifty specialists, but thanks to careful editing, form of entry and scope of the annotations are happily consistent. References to reviews are included in the notes. The extensive list of abbreviations itself constitutes an impressive bibliography of journals and series, and the index of more than 160 columns seems complete and efficient.-J.N.W.

Gibson, R. W. St. Thomas More: a Preliminary Bibliography of His Works and of Moreana to the Year 1750; with a Bibliography of Utopiana compiled by R. W. Gibson and J. Max Patrick. New Haven, Yale University Press, 1961. 499p. facsimiles. $\$ 12.50$.

This extensive bibliography of works by and about St. Thomas More, compiled over a period of ten years, is published by the Yale University St. Thomas More Project and will eventually be revised to include additional materials that the project "will inevitably bring to light" in the course of publishing More's complete works.

Separate sections cover Utopia, other individual works, collected works, letters, biographies, etc., the arrangement within chapters differing according to the material listed. For "lives" and More's important writings, title pages are reproduced in facsimile or given in exact transcription, together with complete collation and location of copies. Citations of the lesser works, Moreana, Utopian bibliography and More portraits contained in the works listed complete the volume. There is an index of authors and works.-R.K.
Texas. University. Humanities Research Center. Catalogue of the Dickens Collection at the University of Texas. Compiled by Mary Callista Carr, C.D.P. Austin, 1961. 195p. (University of Texas Bibliographical Series, 1). $\$ 5$

Dickens scholars should find this a valuable addition to existing Dickens bibliographies, describing as it does a remarkably complete collection of "first editions-in most instances, first issues-of all major and secondary works of Charles Dickens." (Introd.) Included also are a list of Dickens manuscripts in the Texas collection, a section of Dickensiana, and lists of Dickens biographies and bibliographies. Items of special interest are marked with a dagger; those not found recorded in earlier bibliographies, with an asterisk.-E.S.

Thrall, William Flint and Hibbard, Addison. $A$ Handbook to Literature, rev. and enl. by C. Hugh Holman. N. Y., Odyssey Press, 1960. 598p. $\$ 3.75$.

1 st ed. 1936.

A useful handbook covering terms, literary movements, literary periodicals, etc., in one alphabet. The new edition has been revised and enlarged, many new terms added, and many of the older entries rewritten or modified, although others remain substantially as they were. The "Outline of Literary History, English and American," pp. 519-598, has been brought down to 1959 .

Toronto. University. Library. Catalogue of Italian Plays, 1500-1700, in the Library of the University of Toronto compiled by Beatrice Corrigan. [Toronto] University of Toronto Press, 1961. 134p.

This catalog of one of the most complete collections of Italian Renaissance plays in North America gives a brief bibliographical description for each work, identifying it by date, genre, and form and including details of dedications. Wherever possible, editions have been verified in a standard bibliography. Although the listed plays were all written between 1500 and 1700 , eighteenth century editions are given for the most popular ones. Fourteen illustrations taken from various titles in the collection and two additional alphabetical lists, one of the plays' titles and the other of their printers, add to the usefulness of the volume.-E.L.

\section{HISTORY}

Abstracts of New World Archaeology. v.1- . 1959- . Edited by Richard B. Woodbury. Washington, The Society for American Archaeology, 1960- . Annual. \$3.50.

"All published titles dealing expressly with 
New World archaeology ... master's and doctor's theses [and] . . . presentations on archaeological theory, methods, and techniques ... insofar as they seem to be pertinent to New World problems" constitute the scope of this new service. (Introd.) The twenty-eight sections are primarily geographical, e.g., "Arctic," "Northern Mississippi Valley," "Lower Central America," etc., with South America divided by national political units. The editors acknowledge that this is not a perfect arrangement, but believe that it is probably more satisfactory than a purely topical one would be. In this issue there is a total of 676 items, representing books, monographs in series, journal articles, and theses. No list of the journals abstracted is included, but they appear to be, understandably, primarily from the Americas. The abstracts themselves vary in length from a modest paragraph to several columns. There is an author index.- J.N.W.

Bangkok. Chulalongkorn University. Central Library. Bibliography of Material about Thailand in Western Languages. Bangkok, 1960. $325 \mathrm{p}$.

"The first comprehensive subject bibliography of material about Thailand in Western languages ever to be compiled by Thai nationals . . included are books, periodical articles, pamphlets, mimeographed documents, microfilms and films concerning the fields of philosophy and religion, social sciences, language and literature, pure science and applied science, arts and recreation, history, travel, and biography." (Pref.)

Classed arrangement. No index.

Cincinnati. University. Library. The Modern Greek Collection in the Library of the University of Cincinnati: a Catalogue, ed. by Niove Kyparissiotis. Athens, Hestia Pr. for the University of Cincinnati, 1960. 387p.

A catalog of some twelve thousand volumes, including works in many subject fields and in various languages on Greece or published in Greece. Arranged alphabetically by the Greek alphabet.

Conti, Laura. La resistenza in Italia, 25 luglio 1943-25 aprile 1945; saggio bibliografico .... Milano, Feltrinelli [1961] 404p. (Istituto Giangiacomo Feltrinelli).

Nearly five thousand items published by a number of Italian resistance groups are listed here, with note of location in various archives, libraries, and elsewhere in Italy. (Individual issues of serials are separately numbered, so that titles total considerably less than five thousand.) Periodicals and broadsides form the bulk of the listings, but pamphlets, maps, and other miscellaneous materials are also included. Arrangement is by issuing organization, subdivided first by form and then by place of publication. There are indexes by title, place, subject, individual author, and organization.-J.N.W.

Dictionnaire des parlementaires français; notices biographiques sur les ministres, senateurs et deputes français de 1889 a 1940, publie sous la direction de Jean Jolly. . . . v.l- . Paris, Presses Universitaires de France, 1960- . (In progress) 18 n.f. per v.

Contents: v.l. [Lists, p. 3-336] Biographies, A-Azemar, pp. 337-429.

Planned as a continuation of Robert's similar work of 1891 (Guide S113), this will furnish biographical sketches of the members of the Assemblée Nationale for the years indicated. The present volume is devoted primarily to a number of useful tables and lists: all cabinet compositions in chronological order (with an alphabetical list of names), lists of presidents of the Senate and the Chamber of Deputies, and a master list of senators and deputies. The last hundred pages include some two hundred biographical sketches for the letter "A." Although varying in length, most are considerably more than "thumbnail," with conventional information on dates, education, profession, etc., but with most emphasis on the subject's parliamentary career. Those legislators serving after 1889 who are included in Robert are generally omitted. Editorial standards seem high, although articles are unsigned and without bibliographies. When completed, the set will doubtless be a significant addition to the reference collections of a large variety of libraries. No mention is made of the estimated number of volumes or of the publication sched. ule.-J.N.W.

Florinsky, Michael T. McGraw-Hill Encyclopedia of Russia and the Soviet Union. N. Y., McGraw-Hill, 1961. 624p. il. \$23.50.

Designed primarily for the English language reader, this new one-volume encyclopedia treats all aspects of Russian life and history from medieval times to the flights of the astronauts. Many of the articles have been written and signed by outstanding specialists, both from this country and abroad, and some are accompanied by brief bibliographies of works in English. There are many biographical and geographical entries, as well as longer articles on special subjects in Russian economics, government, history, culture, and science. Due to the great need for authoritative information on Russian matters, this work should be a welcome addition to a library.

Gonzalez, Luis. Fuentes de la historia contemporánea de Mexico. Estudio preliminar... 
con la colaboración de Guadalupe Monroy y Susana Uribe. [l.ed. Mexico] El Colegio de Mexico [1961- ] v.l- .

Contents: v.1. Libros y folletos. 527p. \$11.

The first of several projected volumes which will provide an extensive bibliography on the whole range of Mexican culture for 1910-1940, the period of the Mexican Revolution, this volume, devoted to books and pamphlets, is in three main sections: (I) general works, bibliographies, encyclopedias, etc.; (2) maps and physical geography; and (3) physical anthropology and law. Subsequent sections will treat agriculture, labor, politics, religion, education, literature, etc. Each section has numerous subdivisions; a note explaining the scope and arrangement precedes most of the subsections. Full bibliographical information is given, and library locations and annotations accompany many entries. Alphabetical author and subject indices are planned; until these appear, efficient use of the present volume will be somewhat difficult.-E.S.

Saricks, Ambrose. Bibliography of the Frank E. Melvin Collection of Pamphlets of the French Revolution in the University of Kansas Libraries. [Lawrence] University of Kansas Libraries, 1960. 2v. (University of Kansas Publications. Library Series no. 10) $\$ 7.50$.

Lest this collection of nearly sixty-nine hundred pamphlets, like so many valuable caches, lie unused because unknown, the University of
Kansas has issued this unassuming yet welldone checklist. Part I, 1372 anonymous works listed by title, is followed by an author section of 3799 pamphlets and a third grouping of official and corporate publications; the whole should be helpful to those interested in the various aspects of this period of French history -literary, economic, religious, as well as political. A succinct introduction, full imprint information, brief annotations, and a detailed index (pp. 603-674) are other features of this useful work.-E.J.R.

Utechin, S. V. Everyman's Encyclopaedia of Russia. London, J. M. Dent; New York, E. P. Dutton [1961] 623p. il. (Everyman's Reference Library) $\$ 7.95$.

This is the first dictionary-type reference work about Russia to be published in English in recent years. The author, who is senior research officer in Soviet studies at the London School of Economics and Political Science, refers to the work as a cooperative effort, but takes responsibility for the articles on a wide range of topics in social science categories. Biographical entries predominate in the arts, where the articles are signed by contributing specialists, and in science and technology. Geographical place names are included. With such a broad chronological and subject coverage, the articles on each topic are necessarily brief and intended for the nonspecialist, but the over-all impression is one of accuracy in factual information.-E.B.

\section{Nearly $\$ 4$ Million in CLR Grants}

Appropriations totaling nearly four million dollars during the past five years for work on basic library problems are reported in the fifth annual report of the Council on Library Resources, Inc. Though diverse in subject, the projects sponsored by the Council are directed toward a single end: facilitation of ready and unlimited accessibility of the information contained in libraries. The report catalogs grants and contracts totaling $\$ 3,922,097$ during the five-year period. Included in this figure is $\$ 1,557,293$ for grants and contracts during the fiscal year 1960-1961.

Among the projects to which the Council has given support during the past year are two investigations of the possibility of mechanizing large areas of library operation. One study is being carried on in connection with the planning of a new library for the Chicago Undergraduate Division of the University of Illinois. The other study is concerned with the Library of Congress, where certain operations have long been mechanized, but where there is an acute need at this time for a systematic over-all approach.

In the field of mechanical indexing the Council has given support to two projects for the indexing of large bodies of legal literature, one, at the University of Pittsburgh, involving the use of a computer. Though legal literature provides the material of these investigations, as with the projects for mechanizing of library operations, it is hoped that the findings may find general applicability. 